\title{
ОЦІНКА СТРУКТУРНО-ФУКНЦІОНАЛЬНОГО СТАНУ М'ЯЗІВ У РАЗІ НАСЛІДКІВ ПЕРЕЛОМІВ КІСТОК ГОМІЛКИ ЗА ДАНИМИ УЛЬТРА- ЗВУКОВОГО ДОСЛІДЖЕННЯ
}

\section{В.К. Сокол}

Харківський національний медичний університет

Ключові слова:
наслідки
переломів кісток
гомілки,
структурно-
функиіональний
стан м'язів
гомілки,
ультразвукове
досліджсення.
Клінічна та
експериментальна
патологія T.18, №2
(68). С.148-152.
DOI:10.24061/1727-
4338.XVIII.2.68.2019.255
E-mail: sokol_vk@
ukr.net
ukr.net

\begin{abstract}
Мета роботи - дослідити структурно-функиіональні характеристики м'язів гомілки у разі наслідків переломів великогомілкової кістки з використанням методу ультразвукової діагностики.

Матеріал і методи. Матеріал - протоколи клініко-рентгенологічного обстеження 20 хворих із зрощеними закритими переломами кісток гомілки $і$ залишковими деформаціями великогомілкової кістки. Методи дослідження - клінічний, рентгенологічний, функиіональне ультразвукове дослідження м'язів обох гомілок $з$ вивченням якісних і кількісних сонографічних показників стану м'язів ураженої $i$ здорової кіниівки.

Результати. У 18-тьох (90\%) пацієнтів визначалися зрощені переломи обох кісток гомілки; у 2-х (10\%) - ізольований перелом великогомілкової кістки. В усіх спостереженнях реєструвалося залишкове змімення кісткових фрагментів, гіпотрофія м'яких тканин гомілки на бочі перелому $(1,8 \pm 0,6$ см). При сонографії відзначався чіткий, рівний контур м'язів на обох гомілках з практично рівномірним зменшенням товщчини всіх досліджених м'язів та наявністю в них ділянок підвищеної ехогенності і неоднорідної структури. Коефіцієнт гіпотрофії м'язів не перевищував 14,0 $\pm 1,0 \%$. У спокої різниия між коефіцієнтами скоротливості м'язів ураженої та інтактної гомілки становила в середньому 4,6 $\pm 1,1 \%$, зростаючи після навантаження майже вдвічі $(8,2 \pm 0,9 \%)$.

Висновки. Результати порівняльного ультразвукового дослідження м'язів ураженої та інтактної гомілки виявили зміни м'язової структури $і$ зниження ї̈ скоротливості на стороні перелому, які зростають при нетривалому навантаженні.
\end{abstract}

\section{Ключевые слова: $u c x o \partial b l$ переломов костей голени, структурно- функциональное состояние мышиц голени, ультразвуковая диагностика. \\ Клиническая и экспериментальная патология Т.18, №2 (68). C.148-152.}

\section{ОЦЕНКА СТРУКТУРНО-ФУКНЦИОНАЛЬНОГО СОСТОЯНИЯ МЫШЩ ПРИ ПОСЛЕДСТВИЯХ ПЕРЕЛОМОВ КОСТЕЙ ГОЛЕНИ ПО ДАННЫМ УЛЬТРАЗВУКОВОГО ИССЛЕДОВАНИЯ \\ В.К. Сокол}

Цель работы - изучить структурно-функииональные характеристики мыши голени при последствиях переломов большеберияовой кости с использованием метода ультразвуковой диагностики.

Материал и методы. Материал - протоколь клинико-рентгенологического обследования 20 больных со сросшимися закрытыми переломами костей голени и остаточными деформациями большебериовой кости. Методы исследования клинический, рентгенологический, функииональное ультразвуковое исследование мыши обеих голеней с изучением качественных и количественных сонографических показателей состояния мыши пораженной и здоровой конечности.

Результаты. У 18-ти (90\%) пациентов определялись сросшиеся переломы обеих костей голени, у 2-х (10\%) - изолированный перелом большебериовой кости. Во всех наблюдениях регистрировалось остаточное смещение костных фрагментов, гипотрофия мягких тканей голени на стороне перелома $(1,8 \pm 0,6$ см). При сонографии отмечался четкий, ровный контур мыши на обеих голенях с практически равномерным уменьшением толщины всех исследованных мыши и наличием в них участков повышенной эхогенности и неоднородной структуры. Коэффициент гипотрофии мыши не превымал 14,0 $\pm 1,0 \%$. В покое разница между коэффиичиентами сократимости мыши пораженной и интактной голени составляла $в$ среднем 4,6 1 1,1\%, возрастая после нагрузки почти вдвое $(8,2 \pm 0,9 \%)$.

Выводы. Результаты сравнительного ультразвукового исследования мыши пораженной и интактной голени обнаружили изменения мышечной структуры и снижение сократимости на стороне перелома, которые возрастают после непродолжительной нагрузке. 
Key words:

outcomes of

fractures of the leg

bones, structural

and functional

state of the

muscles of the leg,

ultrasound

diagnostics.

Clinical and pathology. Vol.18, №2 (68). P.148-152. experimental

\section{EVALUATION OF THE MUSCLES STRUCTURAL AND FUNCTIONAL STATE DURING THE OUTCOME OF FRACTURE OF THE SHIN BONES ACCORDING TO ULTRASOUND DATA}

\section{V.K. Sokol}

Objective - to study the muscles structural and functional characteristics of the leg muscles with tibial fractures outcomes using the method of ultrasonic diagnostics.

Material and methods. Material: protocols of clinical and radiological examination of 20 patients with a fused closed fractures of shin bones and residual deformities of the tibia. Research methods: clinical, radiological, functional ultrasound examination of the muscles of both legs with the study of qualitative and quantitative sonographic indicators of the muscles' condition of the affected and healthy limbs.

Results. In 18 (90\%) patients, fused fractures of both bones and in 2 (10\%) patients an isolated fused fracture of the tibia were detected. In all cases the residual displacement of bone fragments and the hypotrophy of the tibia soft tissues on the side of the fracture (1.8 $\pm 0.6 \mathrm{~cm})$ were recorded. When performing sonography, a clear even muscle contour was observed on both legs. A practically uniform decrease in the thickness of all the studied muscles, and the presence in them of areas of increased echogenicity and non-uniform structure was recorded. Hypotrophy coefficient of muscle did not exceed $14.0 \pm 1.0 \%$. At rest, the difference between the contractility coefficients of the muscles of the affected and intact lower leg averaged $4.6 \pm 1.1 \%$, almost doubled after exercise $(8.2 \pm 0.9 \%)$.

Conclusions. The results of a comparative ultrasound examination of the muscles of the affected and intact lower leg revealed changes in the muscular structure and a decrease in contractility on the fracture side increasing after a short load.

\footnotetext{
Вступ

Науково-технічний прогрес і урбанізація призвели до зміни структури травматизму з переважанням автотравми [1], за умов якої ізольовані переломи кісток нижніх кінцівок часто супроводжуються значними пошкодженнями прилеглих м'яких тканин [2]. Пошкодження м'яких тканин: розриви м'язів і фасцій, внутрішньом'язові гематоми й імбібіція м'язів кров'ю, особливо при локалізації в періартикулярній ділянці, можуть істотно обмежувати функціональні можливості нижніх кінцівок на будь-якому етапі посттравматичного періоду [3]. При несприятливих результатах механічних травм нижніх кінцівок ушкодження м'яких тканин можуть посилювати завдану шкоду здоров'ю і ступінь стійкої втрати працездатності. Сонографія є методом вибору дослідження структурно-функціонального стану м'яких тканин, що забезпечує кореляцію клінічної симптоматики 3 висновками візуального дослідження, даючи змогу проводити точну діагностику. До переваг сонографії порівняно з магнітно-резонансною томографією відносяться: швидкість проведення ультразвукового дослідження (УЗД), доступність і значно нижча вартість апаратури $[4,5]$. Однак характер ушкоджень м'яких тканин при переломах кісток нижніх кінцівок та їх вплив на результати посттравматичного періоду при експертній оцінці вивчено недостатньо.
}

\section{Мета роботи}

Дослідити структурно-функціональні характеристики м'язів гомілки у випадку наявних наслідків переломів великогомілкової кістки з використанням методу ультразвукової діагностики.

\section{Матеріал і методи дослідження}

Матеріал дослідження - протоколи клініко-рентгенологічного обстеження 20 хворих із зрощеними закрити- ми переломами кісток гомілки і залишковими деформаціями великогомілкової кістки, у яких за підсумками первинної експертної оцінки не встановлено ступінь тяжкості тілесних ушкоджень у зв'язку з розвитком ускладнень в післяопераційному періоді. Усі хворі спостерігалися в ДУ "Інститут патології хребта та суглобів ім.проф. М.І.Ситенка НАМН України" в 2016-2018 р.p. Методи дослідження - клінічний, рентгенологічний, УЗД переднього великогомілкового м'яза, обох головок (латеральної і медіальної) литкового м'яза, а також м'язів, що відводять I палець стопи на обох гомілках. Під час проведення УЗД визначали якісні (контур і структура м'язу, його ехогенність, наявність включень, розривів і зон перебудови) і кількісні (товщина м'язів у спокої і в напрузі, коефіцієнт гіпотрофії і коефіцієнт скоротності м'язів) сонографічні показники стану м'язів ураженої і здорової кінцівки у спокої і після навантаження (ходьба протягом 15 хв).

Ступінь гіпотрофії (СГ) (\% норми) м'язів вирахували за формулою 1 :

$\mathrm{C} \Gamma=\mathrm{Ty} / \mathrm{Tix} 100 \%$,

де Ту - товщина шару ураженого м'яза (мм), Ті товщина шару відповідного інтактного м'яза контралатеральної кінцівки у спокої, яку приймали за норму [6].

СГ характеризував відносне зменшення товщини ураженого м'яза по відношенню до норми. На основі показника СГ визначали коефіцієнт гіпотрофії (КГ) (\%) ураженого м'яза (КГ=100-СГ) [6].

Коефіцієнт скорочення м'яза характеризував різницю його товщини в напруженому та розслабленому стані, тобто відображав амплітуду його скорочення.

Коефіцієнт скорочування (\%) (КС) розрахували за формулою 2:

$\mathrm{KC}=100-\mathrm{Tp} / \mathrm{Tc} \times 100 \%$,

де Тр - товщина м'яза у розслабленому стані, Тс товщина м'яза в скороченому стані. Порівняння показ- 
ника КС на ураженій та інтактній кінцівках дозволяє оцінити ступінь порушень скорочувальних властивостей ураженого м'яза [6].

\section{Результати та їх обговорення}

Середній вік обстежених 20 пацієнтів (16 чоловіків та 4 жінки) із наслідками переломів кісток гомілки становив 42,2 \pm 7,1 року. Переломи кісток правої та лівої гомілки траплялися приблизно з однаковою частотою у 55,0\% (11) та у 45,0\% (9) спостережень відповідно. У всіх пацієнтів залишилася невправлена багатоплощинна (по ширині та/або по довжині, а також кутова) деформація великогомілкової кістки, що вимагала хірургічної корекції.

Картина ультразвукового дослідження характеризувалася у такий спосіб. Контур м'язів був чітким, рівним на обох кінцівках. Ехогенність m.tibialis anterior, caput mediale m.gastrocnemius, caput laterale m.gastrocnemius та m. adductor hallucis ураженої кінцівки у всіх обстежених була підвищеною, структура місцями неоднорідною (рис.), що засвідчує про перебудову м'язової структури. Враховуючи той факт, що за терміном після

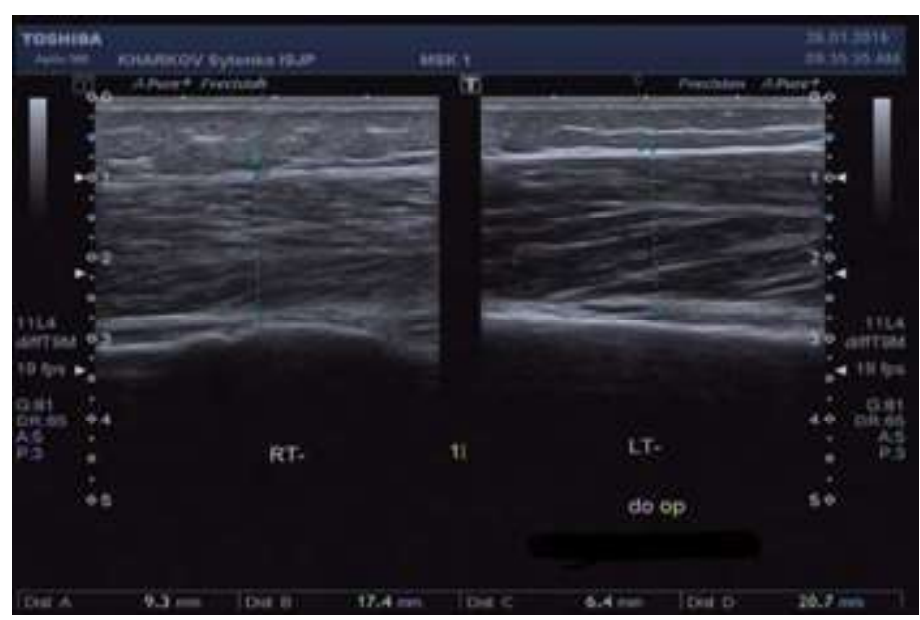

Рисунок. Сонографічне зображення m.tibialis anterior: інтактної (а) та ураженої (б) кінцівок

перелому у всіх хворих спостерігався віддалений посттравматичний період, зони гіперехогенності у м'язах на боці ушкодження відображають рубці з фіброзної волокнистої тканини [7]. Наявність таких рубців призводить до порушення м'язової скорочувальної функції і може негативно впливати на функцію опори і ходьби.

Аналіз результатів порівняльної сонографії ураженої та здорової контрлатеральної кінцівки дав змогу встановити зменшення товщини m.tibialis anterior, caput mediale m.gastrocnemius, caput laterale m.gastrocnemius та $\mathrm{m}$. adductor hallucis на боці перелому. Зменшення товщини вказаних м'язів майже рівномірно виражене в усіх досліджених м'язах. Порівняно з інтактною гомілкою зареєстроване змінення товщини м'язів ураженої кінцівки залишалося в незначних межах. Найбільше зниження скорочувальної можливості спостерігали на m.tibialis anterior - 6,1 \% від скоротливої можливості однойменного інтактного м'яза (табл.).

Таблиця

Статистичні показники функціонального стану м'язів ураженої гомілки хворих 3 наслідками переломів великогомілкової кістки з остаточною деформацією

\begin{tabular}{|c|c|c|c|c|c|}
\hline М'язи & СГ (\%) & КГ(\%) & КСі (\%) & КСу (\%) & $\begin{array}{c}\text { Різниця між КСі } \\
\text { та КСу (\%) }\end{array}$ \\
\hline m.tibialis anterior & $89,2 \pm 1,6$ & $10,8 \pm 1,6$ & $21,6 \pm 1,9$ & $15,5 \pm 1,5$ & 6,1 \\
\hline $\begin{array}{c}\text { caput mediale } \\
\text { m.gastrocnemius, }\end{array}$ & $92,0 \pm 2,7$ & $8,0 \pm 2,7$ & $13,0 \pm 1,4$ & $8,6 \pm 2,1$ & 4,4 \\
\hline $\begin{array}{c}\text { caput laterale } \\
\text { m.gastrocnemius }\end{array}$ & $89,0 \pm 3,6$ & $11,0 \pm 3,6$ & $15,3 \pm 1,4$ & $12,3 \pm 1,4$ & 3,0 \\
\hline m. adductor hallucis & $86,5 \pm 1,0$ & $14,0 \pm 1,0$ & $28,0 \pm 6,0$ & $24,0 \pm 6,0$ & 4,4 \\
\hline
\end{tabular}

Зазначені зміни вказують на зниження скорочувальної здатності м'язів. Їхнє подальше прогресування може призвести до обмеження функціональних можливостей ураженої кінцівки.

Зазвичай після гострої травми більшість незначних м'язових пошкоджень, притаманних неускладненим переломам кісток голмілкі, гояться повністю без ускISSN 1727-4338 https://www.bsmu.edu.ua ладнень [8]. Сполучнотканинні рубці можуть утворитися у разі багатоскалкових переломів кісток гомілки, при переломах 3 великими внутрішньом'язовими і міжм'язової гематомами, у випадках неусунених зміщень кісткових фрагментів і повторних оперативних втручань $[9,10]$.

3 огляду на наявність неусунених посттравматичних Клінічна та експериментальна патологія. 2019. Т.18, №2 (68) 
деформацій великогомілкової кістки, гіперехогенність м'язової тканини виявлено у всіх обстежених хворих, що відображає наявність фіброзніх рубців та $є$ фактором ризику для незворотнього зниження функціональної здатності м'язів ушкодженої кінцівки [11].

\section{Висновки}

1.Виявлена гіперехогенність м'язів гомілки на боці перелому відображає наяність фіброзних волокнистих рубців, які зменшують функціональні можливості ушкодженої нижньої кінцівки.

2.Результати порівняльного ультразвукового дослідження м'язів ураженої та інтактної гомілки виявили витончення м'язової тканини, зміни м'язової структури і зниження м'язової скоротливості на боці перелому, що зростає при нетривалому фізичному навантаженні на кінцівку.

\section{Перспективи подалыших досліджень}

Перспективами подальших досліджень є вивчення взаємозв'язків структурно-функціонального стану м'язів нижніх кінцівок за результатами клінічного тестування та даними сонографії у разі сприятливих та несприятливих наслідків механічних переломів довгих кісток нижніх кінцівок.

\section{Список літератури}

1.Куликов СН. Исходы локальных травм опорно-двигательной системы, неопасных для жизни. Судебная медицина 2017;3(4):12-5. doi: 10.19048/2411-8729-2017-3-4-12-15

2.Lee JC, Healy J. Sonography of lower limb muscle injury. AJR Am J Roentgenol. 2004;182(2):341-51. doi: 10.2214/ajr.182. 2.1820341

3.Imagama S, Hasegawa Y, Ando K, Kobayashi K, Hida T, Ito $\mathrm{K}$, et al. Staged decrease of physical ability on the locomotive syndrome risk test is related to neuropathic pain, nociceptive pain, shoulder complaints, and quality of life in middle-aged and elderly people. The utility of the locomotive syndrome risk test. Mod Rheumatol. 2017;27(6):1051-6. doi: 10.1080/14397595.2017. 1285856

4.Khaladkar SM, Kondapavuluri SK, Kamal A, Kalra R, Kamal V. Detection of myofascial herniation on dynamic sonography and magnetic resonance imaging. Case Rep Radiol [Internet] 2016[cited 2019 Apr 11];2016:ID4245189. Available from: https:/ /www.hindawi.com/journals/crira/2016/4245189/ doi: 10.1155/ 2016/4245189

5.Finlay K, Friedman L. Ultrasonography of the lower extremity. Orthop Clin North Am. 2006;37(3):245-75. doi: 10.10 16/j.ocl.2006.03.002

6.Гайко ОГ. Структурно-функціональні порушення у м'язах хворих з травмою кінцівок. Вісник, ортопедії, травматології та протезування. 2010; 3:28-32.

7.Hida $\mathrm{T}$, Ando $\mathrm{K}$, Kobayashi $\mathrm{K}$, Ito $\mathrm{K}$, Tsushima $\mathrm{M}$, Kobayakawa $\mathrm{T}$, et al. Ultrasound measurement of thigh muscle thickness for assessment of sarcopenia. Nagoya J Med Sci. 2018; 80(4):519-27. doi: 10.18999/nagjms.80.4.519
8.Kasai T, Ishiguro N, Matsui Y, Harada A, Takemura M, Yuki A, et al. Sex- and age-related differences in mid-thigh composition and muscle quality determined by computed tomography in middleaged and elderly Japanese. Geriatr Gerontol Int. 2015;15(6):700-6. doi: $10.1111 /$ ggi.12338

9.Takebayashi S, Takasawa H, Banzai Y, Miki H, Sasaki R, Itoh $\mathrm{Y}$, et al. Sonographic findings in muscle strain injury: clinical and MR imaging correlation. J Ultrasound Med 1995;14(2):899905. doi: 10.7863 jum.1995.14.12.899

10.Pillen S. Skeletal muscle ultrasound. Eur J Transl Myol. 2010;20(4):145-56. doi: 10.4081/ejtm.2010.1812

11.Guerini H, Ayral X, Vuillemin V, Morvan G, Th?venin F, Campagna R, et al. Ultrasound-guided injection in osteoarticular pathologies: General principles and precautions. Diagn Interv Imaging. 2012;93(9):674-9. doi: 10.1016/j.diii.2012.06.010

\section{References}

1.Kulikov SN. Iskhody lokal'nykh travm oporno-dvigatel'noy sistemy, neopasnykh dlya zhizni [The outcomes of the non-life threatening local traumas of the locomotor apparatus]. Russian Journal of Forensic Medicine. 2017;3(4):12-5. doi: 10.19048/ 2411-8729-2017-3-4-12-15 (in Russian).

2.Lee JC, Healy J. Sonography of lower limb muscle injury. AJR Am J Roentgenol. 2004;182(2):341-51. doi: 10.2214/ajr. 182.2.1820341

3. Imagama S, Hasegawa Y, Ando K, Kobayashi K, Hida T, Ito $\mathrm{K}$, et al. Staged decrease of physical ability on the locomotive syndrome risk test is related to neuropathic pain, nociceptive pain, shoulder complaints, and quality of life in middle-aged and elderly people. The utility of the locomotive syndrome risk test. Mod Rheumatol. 2017;27(6):1051-6. doi: 10.1080/14397595.2017. 1285856

4.Khaladkar SM, Kondapavuluri SK, Kamal A, Kalra R, Kamal V. Detection of myofascial herniation on dynamic sonography and magnetic resonance imaging. Case Rep Radiol [Internet]. 2016[cited 2019 Apr 11];2016:ID4245189. Available from: https:/ /www.hindawi.com/journals/crira/2016/4245189/ doi: 10.1155/ $2016 / 4245189$

5.Finlay K, Friedman L. Ultrasonography of the lower extremity. Orthop Clin North Am. 2006;37(3):245-75. doi: 10.10 16/ j.ocl.2006.03.002

6. Гайко ОГ. Структурно-функціональні порушення у м'язах хворих з травмою кінцівок. Вісник, ортопедії, травматології та протезування. $2010 ; 3: 28-32$.

7.Hida T, Ando K, Kobayashi K, Ito K, Tsushima M, Kobayakawa $T$, et al. Ultrasound measurement of thigh muscle thickness for assessment of sarcopenia. Nagoya J Med Sci. 2018;80(4):519-27. doi: 10.18999/nagjms.80.4.519

8.Kasai T, Ishiguro N, Matsui Y, Harada A, Takemura M, Yuki A, et al. Sex- and age-related differences in mid-thigh composition and muscle quality determined by computed tomography in middleaged and elderly Japanese. Geriatr Gerontol Int. 2015;15(6):700-6. doi: $10.1111 /$ ggi.12338

9.Takebayashi S, Takasawa H, Banzai Y, Miki H, Sasaki R, Itoh $\mathrm{Y}$, et al. Sonographic findings in muscle strain injury: clinical and MR imaging correlation. J Ultrasound Med 1995;14(2):899905. doi: $10.7863 /$ jum.1995.14.12.899

10.Pillen S. Skeletal muscle ultrasound. Eur J Transl Myol. 2010;20(4):145-56. doi: 10.4081/ejtm.2010.1812

11.Guerini H, Ayral X, Vuillemin V, Morvan G, Th?venin F, Campagna R, et al. Ultrasound-guided injection in osteoarticular pathologies: General principles and precautions. Diagn Interv Imaging. 2012;93(9):674-9. doi: 10.1016/j.diii.2012.06.010

\section{Відомості про авторів:}

Сокол В.К. - к.мед.н., доцент кафедри судової медицини, медичного правознавства ім. засл. проф. М.С. Бокаріуса Харківського національного медичного університету

\section{Сведения об авторах:}

Сокол В. К. - к.мед.н., доцент кафедры судебной медицины, медицинского правоведения им. засл. проф. М.С. Бокариуса Харьковского национального медицинского университета 
Information about authors:

Sokol V. K. - PhD, Associate Professor of the Department of Forensic Medicine, Medical Law named after prof. M.S. Bokarius of Kharkiv National Medical University 